Studia nad Autorytaryzmem i Totalitaryzmem 43, nr 1

Wrocław 2021

https://doi.org/10.19195/2300-7249.43.1.15

\author{
JÓZEF KOREDCZUK \\ ORCID: 0000-0002-3471-586X \\ Uniwersytet Wrocławski \\ jozef.koredczuk@uwr.edu.pl
}

\title{
Koncepcje eugeniczne w polskiej nauce kryminologii w okresie międzywojennym (aspekty prawno-kryminalne)
}

Słowa kluczowe: eugenika, kryminologia, okres międzywojenny, prawo karne, przestępczość, sterylizacja.

\section{EUGENIC CONCEPTS IN THE POLISH SCIENCE OF CRIMINOLOGY \\ IN THE INTERWAR PERIOD (LEGAL AND CRIMINAL ASPECTS)}

\begin{abstract}
The aim of the article is to show the role of eugenic concepts in the views of Polish legal criminologists looking for solutions to reduce crime. One way they considered was castration and especially sterilization of criminals, believing that the propensity to commit crimes is hereditary. These concepts raised great moral and ethical doubts as well as legal ones. Most of them met with opposition from Polish lawyers, but were still popular due to the influence of the anthropological school in the study of criminal law. In the 1930s, the solutions were adopted in German law.
\end{abstract}

Keywords: eugenics, criminology, interwar period, criminal law, crime, sterilization.

Kwestie o charakterze eugenicznym należą do najbardziej dyskusyjnych problemów w prawie, wywołujących wiele sporów i wątpliwości. Mamy z nimi do czynienia w różnych gałęziach prawa (na przykład w zakresie prawa rodzinnego czy kanonicznego). Ze szczególnie burzliwymi dyskusjami na temat znaczenia kwestii eugenicznych mamy zwłaszcza na gruncie prawa karnego. 
Po raz pierwszy problemy o charakterze eugenicznym stały się przedmiotem szerokiej debaty w polskiej nauce kryminologii w okresie międzywojennym. Stało się tak zarówno pod wpływem czynników wewnętrznych, jak i zewnętrznych. Zwrot w stronę eugeniki ze strony karnistów polskich nastąpił w związku z poszukiwaniem różnych dróg zapobiegania przestępczości, w ramach której jednym $\mathrm{z}$ ewentualnych środków, po które planowano sięgnąć, była przymusowa sterylizacja niektórych przestępców. Niemały wpływ na zwrócenie uwagi karnistów na kwestie eugeniczne miały teorie Cesarego Lombroso - niezwykle popularne na przełomie XIX i XX wieku — o urodzonym przestępcy, które były wykorzystywane do propagowania kastracji i sterylizacji. Ze względu na fakt, że zabiegi sterylizacyjne budziły olbrzymie kontrowersje, ich stosowanie brano pod uwagę jako środek zabezpieczający o charakterze eugenicznym w stosunku do przestępców niepoprawnych lub mogących przekazać swe cechy psychopatologiczne potomstwu w drodze dziedziczenia ${ }^{1}$. Znacznie rzadziej natomiast rozważano drugi, bardziej drastyczny środek o charakterze eugenicznym, jakim była kastracja.

Sięganie po środki eugeniczne w prawie karnym częściowo uzasadniano argumentami medycznymi. Typowym przykładem może być tu wypowiedź Wacława Makowskiego, który stwierdził, że „Społeczeństwo broni się przeciw szkodliwym jednostkom jak przeciw zaraźliwym chorobom, aby uniknąć grożącego dla nich niebezpieczeństwa [...] nie może bawić się w półśrodki"2 . Zaś inny prawnik polski Stanisław Buczyński, odnosząc się do praw dziedziczenia przestępczości, głosił, że państwo - w myśl idei eugenicznej — „powinno być świadomym hodowcą swego narodu"3. Natomiast przeciwna argumentacja, odwołująca się do prawa karnego, polegała na usprawiedliwianiu sterylizacji, sięgając przy tym do instytucji stanu wyższej konieczności, gdzie ze względu na większą niż u osób zdrowych rozrodczość osobników dziedzicznie obciążonych cechami niepożądanymi była ona zasadna ${ }^{4}$.

W okresie międzywojennym można było spotkać postulaty rozszerzenia katalogu kar przewidywanych wobec osób dokonujących gwałtów, szczególnie tych dokonywanych na dzieciach. Pojawiły się pomysły wprowadzenia kary sterylizacji wobec wielokrotnych gwałcicieli ${ }^{5}$. Za wprowadzeniem przymusowej sterylizacji niektórych przestępców wypowiedział się początkowo między innymi najwybitniejszy polski karnista, Juliusz Makarewicz. Twierdził on, że jednostka zaliczająca się do przestępców stałych (zawodowych, nałogowych, anormalnych

1 J. Nelken, Polska myśl kryminologiczna od schyłku XIX w. do 1939 r., „Archiwum Kryminologii" 13, 1986, s. 224.

2 Cyt. za: E. Janiszewska-Talago, Szkoła antropologiczna prawa karnego, Warszawa 1965, s. 46.

3 S. Buczyński, Sprawa urzędnicza a eugenika, „Zagadnienia Rasy” 4, 1929, nr 7-8, s. 350.

${ }^{4}$ L. Górnicki, Prawo Trzeciej Rzeszy w nauce i publicystyce prawniczej Polski Międzywojennej (1933-1939), Bielsko-Biała 1993, s. 180.

5 W. Grzywo-Dąbrowski, Zagadnienie obezpłodnienia, „Praca i Opieka Społeczna” 1935, nr 4, s. 554 . 
lub częściowo anormalnych) nie powinna mieć możliwości pozostawienia po sobie potomstwa, z czego wynika wymóg jej sterylizacji ${ }^{6}$. Za kastracją opowiadał się natomiast w stosunku do przestępców seksualnych. Poglądy te podtrzymywał Makarewicz jeszcze w 1924 roku w swoim podręczniku do prawa karnego, powołując się na osiągnięcia eugeniki ${ }^{7}$. Później jednak z nich się wycofał i nigdy do nich nie wrócit ${ }^{8}$. Przyczyn zmiany stanowiska zasłużonego karnisty w sprawie rozwiązań eugenicznych niektórzy dopatrują się w uznaniu ich przez niego za niehumanitarne, sprzeczne z poszanowaniem godności człowieka. Makarewicz przyjął wtedy założenie, że wystarczającą metodą zapobiegania przestępczości na gruncie prawa karnego jest instytucja długotrwałego internowania przestępców chronicznych w zakładach zabezpieczających ${ }^{9}$.

Do postulatów szkoły antropologicznej odwoływał się również adwokat Stefan Markusfeld, który rozważając naturę dziedziczenia cech u przestępców i ich kompilację występującą u człowieka, uważał, że można określić jego predyspozycje w kierunku chorób psychicznych lub skłonności do przestępstwa. Przy tym postrzegał on prawa eugeniki jako nieubłagane, determinujące życie człowieka, a więc upoważniające do reakcji ze strony innych ludzi, państwa ${ }^{10}$.Za „oczyszczeniem" społeczeństwa z jednostek niepożądanych opowiadał się również sędzia Artur Miller, który wśród konkretnych działań obejmujących walkę ze zwyrodnieniem wyróżniał sterylizację. Swoje propozycje w tym względzie opierał na doświadczeniach amerykańskich. Krytycznie jednak oceniał, że nie znajdą one w tym czasie odpowiedniej liczby sympatyków w Polsce, by regulacje o charakterze eugenicznym znalazły się w ustawodawstwie polskim. W roku 1928 było na nie zdecydowanie za wcześnie ${ }^{11}$.

Sytuacja zmieniła się po wydaniu i wejściu w życie kodeksu karnego ${ }^{12}$ z 1932 roku, bowiem niektórzy z autorów piszących o eugenice zaczęli się odnosić do jego postanowień. Zwolennikiem niektórych rozwiązań eugenicznych był wileński prawnik Grzegorz Wirszubski, który podkreślał, że „nóż chirurga działa równie szybko i gruntownie jak topór kata"13. Zwracał on również uwagę, że prewen-

6 J. Makarewicz, Zbrodnia i kara, Lwów 1922, s. 139.

7 J. Makarewicz, Prawo karne. Wykład porównawczy z uwzględnieniem prawa obowiazującego w Rzeczypospolitej Polskiej, Lwów 1924, s. 43.

${ }^{8}$ F. Ciepły, Środki zabezpieczajace według koncepcji Juliusza Makarewicza, [w:] Prawo karne w pogladach profesora Juliusza Makarewicza, red. A. Grześkowiak, Lublin 2005, s. 299.

9 P. Góralski, Środki zabezpieczające w polskim prawie karnym, Warszawa 2015, s. 37-38.

10 S. Markusfeld, Zbrodnia, dziedziczność a eugenika, „Zagadnienia Rasy” 5, 1931, nr 1, s. 54-55; idem, Eugenika - nauka o hodowli ludzi - a prawo, „Zagadnienia Rasy” 4, 1928, nr 1, s. 200.

11 A. Miller, Ustawodawstwo eugeniczne zagranica i u nas, „Zagadnienia Rasy” 4, 1928, nr 1, s. 26-27, 29.

12 Rozporządzenie Prezydenta Rzeczypospolitej z dnia 11 lipca 1932 roku — Kodeks karny (Dz.U. RP nr 60, poz. 571).

13 Warto jednak w tym miejscu przywołać wypowiedź innego prawnika, Henryka Żółtowskiego, który pisał, że kastracja jednak była mieczem obosiecznym: o ile z jednej strony spełnia- 
cyjna polityka kryminalna, mająca na celu zmniejszenie przestępczości, kroczy częściowo wspólnym szlakiem z eugeniką. Ta bowiem walczy ze zwyrodnieniem, usuwając niegodne przekazania dobra dziedziczne, zaś prewencyjna polityka kryminalna wymaga usunięcia przestępnych skłonności dziedzicznych. Co ciekawe, opowiadał on się za dalej idącą w skutkach niż sterylizacja kastracją ${ }^{14}$. Twierdził on, że być może kastracja nadaje się do odciążenia zakładów dla niepoprawnych oraz budzi mniejsze opory, ponieważ dotyczy niebezpiecznych przestępców, których nie można poskromić zwykłymi środkami. Przeciwny był natomiast przymusowej sterylizacji, zwracając uwagę, że przeciwko jej wprowadzeniu przemawia nie tylko niepewność praw dziedziczenia, lecz przede wszystkim przymusowość tego zabiegu pozostaje w sprzeczności z zasadami humanitaryzmu ${ }^{15}$.

Pod koniec lat trzydziestych wprowadzenie sterylizacji do systemu prawa jako jednego ze środków profilaktyki kryminalnej postulował także prokurator Sądu Najwyższego Stanisław Czerwiński, który uznawał wpływ dziedziczności na przestępczość, zwłaszcza tę chroniczną. Sterylizacja według niego była jednym ze środków profilaktyki przeciwprzestępczej, polegającej na zwalczaniu zwyrodnienia ludności. Czerwiński opowiadał się za sterylizacją eugeniczną, to jest „mającą na celu podniesienie rasy ludzkiej"16.

Sterylizację dopuszczał także Henryk Żółtowski, choć nie godził się z tezą, że zachowania przestępcze są dziedziczne. Akceptował ją jednak ze względów społeczno-ekonomicznych, uważając, że przestępcy zawodowi, nałogowi, a także wielokrotni recydywiści nie nadają się do wykonywania społecznej funkcji utrzymania rodziny i wychowywania dzieci, toteż nie powinni mieć fizycznej możliwości ich poczęcia ${ }^{17}$. Sterylizacja ze względów społeczno-ekonomicznych, według niego, obejmowała znacznie szerszy zakres zjawisk niż sterylizacja eugeniczna, uznająca dziedziczność przestępstwa. Nieuznawanie przez Żółtowskiego dziedziczności przestępstwa powodowało, że propagowaną przez niego sterylizację

ła niewątpliwie swoje zadanie społeczne, uniemożliwiając rozrodczość tam, gdzie jej zabraniał wzgląd na dobro ogółu, o tyle równocześnie przynosiła ciężką szkodę jednostce w postaci głębokiego wstrząsu psychofizycznego i pozbawienia charakteru płci —idem, Obezpłodnienie wświetle nauk spotecznych, „Higiena Psychiczna” 1935, nr 3-5, s. 135.

14 Kastracja bowiem wykluczała możność zapłodnienia oraz zmniejszała popęd płciowy i zdolność spółkowania. Natomiast sterylizacja wykluczała tylko zdolność zapłodnienia, lecz nie zmniejszała popędu płciowego — zob. G. Wirszubski, Ubezpłodnienie przymusowe, jako środek walki z przestępczością, „Rocznik Prawniczy Wileński” 7, 1935, s. 129-130, 132.

15 Ibidem, s. 146, 153.

16 S. Czerwiński, Dziedziczność a przestęstwa chroniczne, „Zagadnienia Rasy” 1937, nr 3, s. 331; idem, Sterylizacja i przerwanie ciąży w świetle walki z przestępczościa, „Zagadnienie Rasy” 1936, nr 1.

${ }^{17}$ F. Ciepły, Filozoficzne aspekty regulacji nieleczniczych środków zabezpieczajacych w polskim kodeksie karnym z 1932 r., [w:] Probłemy derżawotworenniai zachystu praw ludyny w Ukrayini. Materiały X rahionalnoji naukowo-praktyczno konferencji (5-6 lutego 2004 r.), Lwiw 2004, s. 132; idem, Geneza nieleczniczych środków zabezpieczających w polskim prawie karnym, cz 1. Kontekst społeczno-historyczny, „Przegląd Prawno-Ekonomiczny” 2014, nr 28, s. 35-36. 
ze względów społeczno-ekonomicznych można uznać za quasi-sterylizację kryminologiczną, ponieważ nie każde źle wychowane lub zaniedbane dziecko musi wyrosnąć na przestępcę. Jako podstawy do sterylizacji ze wskazań społeczno-ekonomicznych wskazywał on bowiem: zawodowe popełnianie przestępstw, wybitną słabość umysłową (upośledzenie umysłowe) i ciężki chroniczny alkoholizm, które powodowały, że osoby nimi dotknięte nie nadawały się do wykonywania społecznej funkcji utrzymania rodziny i wychowania dzieci, a więc nie powinny ich miećc ${ }^{18}$. W wielu cywilizowanych krajach w pierwszych latach XX wieku obserwowano bowiem zjawisko nazywane przez uczonych „schamieniem narodu”. Polegało ono na powolnym procesie obniżania się liczby jednostek silnych, wartościowych, a zarazem wzroście grupy jednostek słabych, niezdolnych do pełnienia swoich obywatelskich obowiązków i tym samym obniżających ,jakość narodu"19.

Ze względu na ewentualne opory ze strony społeczeństwa Żółtowski opowiadał się za tym, by sterylizację przymusową powiązać z faktem popełnienia przestępstwa. Dlatego też postulował wprowadzenie sterylizacji w charakterze środka zabezpieczającego do kodeksu karnego. Poddanie wtedy takiemu zabiegowi osób jej podlegających nie sprawiłoby trudności i uchroniłoby społeczeństwo od poważnej liczby najważniejszych szkodników społecznych, nie wywołując przy tym sprzeciwów, które spowodowałaby czysto prewencyjna ustawa sterylizacyjna. Skoro sterylizacja jako jeden ze środków zabezpieczających nie znalazła się w kodeksie karnym z 1932 roku, Żółtowski proponował nowelizację jego rozdziału 12, określającego środki zabezpieczające. Miałby on według niego wyglądać następująco:

Art. 79. § 1. Jeżeli sprawcę czynu zabronionego pod groźbą kary uznano za nieodpowiedzialnego, a jego pozostawanie na wolności grozi niebezpieczeństwem porządkowi prawnemu, sąd zarządza jego umieszczenie w zamkniętym zakładzie dla psychicznie chorych albo w innym zakładzie leczniczym. § 2. Jeżeli takiego sprawcę uznano za niezdolnego do utrzymania lub wychowania potomstwa, sąd może zarządzić dokonanie zabiegu chirurgicznego, który bez naruszenia gruczołów płciowych pozbawi sprawcę zdolności rozrodczej.

Art. 80. § 1. Jeżeli przestępcę uznano za mającego zmniejszoną zdolność rozpoznawania lub kierowania postępowaniem (art. $18 \S 1^{20}$ ), a jego pozostawanie na wolności grozi niebezpieczeństwem porządkowi prawnemu, sąd może zarządzić jego umieszczenie w zamkniętym zakładzie dla psychicznie chorych albo w innym zakładzie leczniczym. § 2. Niezależnie od umieszczenia w zakładzie sąd może zastosować art. 79 § 2 . 3 . Jeżeli takiego przestępcę sąd skazał na karę pozbawienia wolności, to o tym, czy orzeczoną karę wykonać, sąd rozstrzyga po zwolnieniu przestępcy z zakładu leczniczego.

Art. 81. Czas pobytu w zakładach wymienionych w art. 79 i 80 nie oznacza się z góry. Sąd nie może zarządzić zwolnienia z zakładu wcześniej niż po upływie jednego roku, może zaś zwolnienie uzależnić od poddania się zabiegowi wymienionemu w art. 79 § 2.

18 H. Żółtowski, Obezpłodnienie w Polsce. Zarys problemu de lege lata $i$ de lege ferenda, „Higiena Psychiczna” 1935, nr 6-7, s. 213.

19 H. Żółtowski, Wyjałowienie w ramach eugeniki, „Eugenika Polska” 11, 1937, nr 4, s. 276.

20 Art. 18 § 1: „Jeżeli w chwili popełnienia przestępstwa zdolność rozpoznawcza znaczenia czynu lub kierowania postępowaniem była w znacznym stopniu ograniczona, sąd może zastosować nadzwyczajne złagodzenie kary”. 
Art. 82. § 1. Jeżeli czyn pozostaje w związku z nadużyciem napojów wyskokowych lub innych środków odurzających, sąd może zarządzić, by sprawcę, po ewentualnym odbyciu wymienionej kary, umieszczono w odpowiednim zakładzie leczniczym na przeciąg dwóch lat. § 2. Niezależnie od umieszczenia w zakładzie sąd może zastosować art. 79 § 2. § 3 . O wcześniejszym zwolnieniu z zakładu rozstrzyga sąd, który może je uzależnić od poddania się zabiegowi wymienionemu w art. $79 \S 2$.

Art. 83. § 1. Jeżeli czyn pozostaje w związku ze wstrętem do pracy, sąd może zarządzić, by po odbyciu kary umieszczono przestępcę $\mathrm{w}$ domu pracy przymusowej na przeciąg lat 5 . $\S 2$. Niezależnie od umieszczenia w domu pracy przymusowej sąd może zastosować art. $79 \S 2$. Art. 84. § 1. Sąd zarządza umieszczenie w zakładzie dla niepoprawnych po odbyciu kary przestępcy, u którego stwierdzono trzykrotny powrót do przestępstwa (art. $60 \S 1^{21}$ ), tudzież przestępcy zawodowego lub z nawyknienia, jeżeli pozostawanie ich na wolności grozi niebezpieczeństwem porządkowi prawnemu $\S 2$. Niezależnie od umieszczenia w zakładzie sąd może zastosować art. $79 \S 2$. 3 . Zamknięcie w zakładzie trwa w miarę potrzeby, w każdym razie najmniej 5 lat; po upływie każdego pięcioletniego okresu sąd rozstrzyga, czy pozostawanie przestępcy w zakładzie na dalszy okres pięcioletni jest konieczne, jak również, czy zwolnienie należy uzależnić od poddania się zabiegowi wymienionemu w art. $79 \S 2^{22}$.

Największe zainteresowanie prawników polskich problematyką eugeniczną miało miejsce po przyjęciu stosownych rozwiązań w prawie niemieckim, zwłaszcza ustawy z dnia 14 lipca 1933 roku o zapobieganiu dziedzicznie choremu potomstwu ${ }^{23}$. Wielu spośród nich szczegółowo je analizowało, znacznie rzadziej natomiast prawnicy wypowiadali się za wprowadzeniem analogicznych rozwiązań w prawie polskim. Jednym z ich zwolenników był ppłk audytor Stanisław Albert ${ }^{24}$, który opowiedział się za sterylizacją, ale głównie z powodów ekonomicznych, wskazując na jej znaczenie społeczne. Nie odniósł się jednak w tym względzie ani słowem do sytuacji w Polsce. Z ppłk. Albertem nie zgadzał się inny audytor wojskowy, Tadeusz Rozwoda ${ }^{25}$. Odrzucał on jednak sterylizację nie z powodów ekonomicznych czy społecznych, lecz religijnych, twierdząc, że jest ona sprzeczna z mesjanizmem ${ }^{26}$.

Natomiast najbardziej gorącą dyskusję w kwestiach eugenicznych wśród prawników polskich wywołało pojawienie się w latach 1934-1935 polskich projektów ustawy sterylizacyjnej. Generalnie przyjęto je krytycznie, opowiadając się

21 Art. 60 § 1: „Jeżeli sprawca w ciągu 5 lat po odbyciu kary w kraju lub za granicą, w całości lub przynajmniej w trzeciej części, albo w ciągu 5 lat po uwolnieniu z zakładu zabezpieczającego, popełni nowe przestępstwo z tych samych pobudek lub należące do tego samego rodzaju, co poprzednie, sąd może wymierzyć karę wyższą o połowę od najwyższego wymiaru kary, nie przekraczającej jednak ustawowej granicy danego rodzaju kary. Jeżeli ustawa daje sądowi możność wyboru między karą więzienia a karą aresztu, nie można wymierzyć kary aresztu".

${ }^{22}$ H. Żółtowski, Obezpłodnienie w Polsce..., s. 213-214.

23 Zob. jej charakterystykę w: M. Gawin, Rasa i nowoczesność. Historia polskiego ruchu eugenicznego (1880-1952), Warszawa 2003, s. 247-252.

24 Por. S. Albert, Kwestia sterylizacji i jej znaczenie spoteczne na tle niemieckiej ustawy karnej z dn. 14 lipca 1933 r., „Wojskowy Przegląd Prawniczy” 10, 1937, nr 3, s. 231-243.

25 Por. T. Rozwoda, Krytyczne uwagi o sterylizacji i jej znaczeniu spotecznym, „Wojskowy Przegląd Prawniczy" 10, 1937, nr 4.

${ }^{26}$ L. Górnicki, op. cit., s. 180-181. 
przeciw ich uchwaleniu (taką opinię wyraził na przykład Jan Rembieliński, działacz Stronnictwa Narodowego). Zdarzały się jednak także głosy je aprobujące. Przykładowo anonimowy adwokat w artykule z 1936 roku opowiadał się za przyjęciem ustaw eugenicznych, uważał bowiem, że sterylizacja nie ma charakteru represyjnego, ale jest „rodzajem ubezpieczenia społeczeństwa” przed „możliwością działania występnego" oraz środkiem zmniejszenia ciężarów opieki społecznej27.

Wprowadzenie do prawa karnego rozwiązań uwzględniających uwarunkowania o charakterze eugenicznym uzasadniano na ogół względami społecznymi, obyczajowymi, religijnymi czy zdrowotnymi. Tym właśnie różniły się projekty polskich aktów prawnych o charakterze eugenicznym w okresie międzywojennym od ustawodawstwa z zakresu higieny rasowej w III Rzeszy, które miało podstawy rasowe $^{28}$. Zwolennikami ich wprowadzenia byli przede wszystkim lekarze, którzy nie uważali kastracji i sterylizacji za przestępstwo, lecz za jeden ze sposobów leczenia osób dotkniętych niektórymi chorobami.

W Polsce sympatycy sterylizacji stanowili zdecydowaną mniejszość. Dowodem negatywnego stosunku polskich prawników do niej może być także fakt, że propozycja wprowadzenia nieleczniczego środka zabezpieczającego w postaci przymusowej sterylizacji nie pojawiła się w trakcie obrad Komisji Kodyfikacyjnej29. Także po wejściu w życie kodeksu karnego z 1932 roku czołowy polski karnista Władysław Wolter podkreślał, że zabiegi pozbawiające płodności w świetle prawa polskiego można byłoby uznać za przestępstwo, bez względu nawet na to, czy sterylizacja zostałaby przeprowadzona ze względów klinicznych, profilaktycznych, eugenicznych bądź społecznych, i byłaby przyjęta za akt prawny ${ }^{30}$.

Prawnicy polscy podkreślali, że dla kryminologii sprawa sterylizacji miała znaczenie wtórne. Była ona bowiem przede wszystkim zagadnieniem medycznym. Z prawem karnym łączyła się ona w ten sposób, że współczesne pojęcia $z$ tej dziedziny schodziły z płaszczyzny suchego paragrafizmu, doktrynerstwa i dogmatycznej egzegezy na płaszczyznę czystej walki z przestępstwem. Była ona celem prawa karnego, zawartych w kodeksie karnym przepisów oraz wskazówek o ochronie społeczeństwa przed asocjalnymi jednostkami czy przestępcami ${ }^{31}$. Jedynym prawnikiem polskim, który zaproponował przekucie koncepcji eugenicznych w konkretne przepisy karne, był wspomniany Henryk Żółtowski.

Kwestie eugeniczne w prawie karnym, mimo że odgrywają niezwykle istotną rolę, stanowią „kwadraturę koła”, której nie odważył się podjąć ustawodaw-

27 Jednostka w zbiorowisku — rodzina, „ABC” 1936, nr 4, s. 4; M. Gawin, op. cit., s. 260-261.

28 F. Połomski, Spór o stosowanie hitlerowskiego ustawodawstwa sterylizacyjnego do Polaków na terenie Opolszczyzny, „Studia Śląskie. Seria nowa” 3, 1960, s. 191.

29 F. Ciepły, Geneza nieleczniczych..., s. 36-37.

$30 \mathrm{~W}$. Wolter, Uwagi prawnicze na marginesie projektu ustawy engenicznej, „Zagadnienia Rasy" 1935, nr 3, s. 203.

31 A. Nowowsielski, Problem sterylizacji, „Czasopismo Sędziowskie” 9, 1935, nr 5, s. 276 277. 
ca w okresie międzywojennym, natomiast poruszywszy ją współcześnie, bardzo szybko z tego się wycofał. Potwierdzeniem tego są losy art. 95a § 1 kodeksu karnego $^{32}$ z 1997 roku, który wprowadzony do tego zbioru przepisów w wyniku nowelizacji dokonanej we wrześniu 2009 roku, przewidywał możliwość skierowania na leczenie ambulatoryjne w celu przeprowadzenia terapii farmakologicznej — czyli de facto kastracji farmakologicznej — wobec sprawców przestępstw przeciwko wolności seksualnej. Zapis ten obowiązywał niecałe sześć lat, do końca czerwca 2015 roku.

\section{Bibliografia}

\section{Literatura}

Albert S., Kwestia sterylizacji i jej znaczenie społeczne na tle niemieckiej ustawy karnej z dn. 14 lipca 1933 r., „Wojskowy Przegląd Prawniczy” 1937, r. 10, nr 3.

Buczyński S., Sprawa urzędnicza a eugenika, „Zagadnienia Rasy” 1929, t. 4, nr 7-8.

Ciepły F., Filozoficzne aspekty regulacji nieleczniczych środków zabezpieczających w polskim kodeksie karnym z 1932 r., [w:] Probłemy derżawotworenniai zachystu praw ludyny w Ukrayini. Materiaty X rahionalnoji naukowo-praktyczno konferencji (5-6 lutego 2004 r.), Lwiw 2004.

Ciepły F., Geneza nieleczniczych środków zabezpieczających w polskim prawie karnym. Część 1. Kontekst społeczno-historyczny, „Przegląd Prawno-Ekonomiczny” 2014, nr 28.

Ciepły F., Środki zabezpieczające wedtug koncepcji Juliusza Makarewicza, [w:] Prawo karne w pogladach profesora Juliusza Makarewicza, red. A. Grześkowiak, Lublin 2005.

Czerwiński S., Dziedziczność a przestępstwa chroniczne, „Zagadnienia Rasy” 1937, nr 3.

Czerwiński S., Sterylizacja i przerwanie ciąży w świetle walki z przestępczościa, „Zagadnienia Rasy" 1936, nr 1.

Gawin M., Rasa i nowoczesność. Historia polskiego ruchu eugenicznego (1880-1952), Warszawa 2003.

Góralski P., Środki zabezpieczajace w polskim prawie karnym, Warszawa 2015.

Górnicki L., Prawo Trzeciej Rzeszy w nauce i publicystyce prawniczej Polski Międzywojennej (1933-1939), Bielsko-Biała 1993.

Grzywo-Dąbrowski W., Zagadnienie obezpłodnienia, „Praca i Opieka Społeczna” 1935, nr 4.

Janiszewska-Talago E., Szkoła antropologiczna prawa karnego, Warszawa 1965.

Jednostka w zbiorowisku - rodzina, „ABC” 1936, nr 4.

Makarewicz J., Prawo karne. Wykład porównawczy z uwzględnieniem prawa obowiazujacego w Rzeczypospolitej Polskiej, Lwów 1924.

Makarewicz J., Zbrodnia i kara, Lwów 1922.

Markusfeld S., Eugenika - nauka o hodowli ludzi - a prawo, „Zagadnienia Rasy” 1928, t. 4, nr 1.

Markusfeld S., Zbrodnia, dziedziczność a eugenika, „Zagadnienia Rasy” 1931, t. 5, nr 1.

Miller A., Ustawodawstwo eugeniczne zagranica i u nas, „Zagadnienia Rasy” 1928, t. 4, nr 1.

Nelken J., Polska myśl kryminologiczna od schytku XIX w. do 1939 r., „Archiwum Kryminologii” 1986, t. 13.

Nowowsielski A., Problem sterylizacji, „Czasopismo Sędziowskie” 1935, t. 9, nr 5.

Połomski F., Spór o stosowanie hitlerowskiego ustawodawstwa sterylizacyjnego do Polaków na terenie Opolszczyzny, „Studia Śląskie. Seria nowa” 1960, t. 3.

32 Ustawa z dnia 6 czerwca 1997 roku — Kodeks karny (Dz.U. z 2020 r. poz. 1444, 1517). 
Rozwoda T., Krytyczne uwagi o sterylizacji i jej znaczeniu społecznym, „Wojskowy Przegląd Prawniczy" 1937, R. 10, nr 4.

Wirszubski G., Ubezpłodnienie przymusowe, jako środek walki z przestępczościa, ,,Rocznik Prawniczy Wileński” 1935, R. 7.

Wolter W., Uwagi prawnicze na marginesie projektu ustawy eugenicznej, „Zagadnienia Rasy” 1935, t. 10, nr 3.

Żółtowski H., Obezpłodnienie w Polsce. Zarys problemu de lege lata $i$ de lege ferenda, „Higiena Psychiczna" 1935, nr 6-7.

Żółtowski H., Obezpłodnienie w świetle nauk społecznych, „Higiena Psychiczna” 1935, nr 3-5.

Żółtowski H., Wyjałowienie w ramach eugeniki, „Eugenika Polska” 1937, t. 11, nr 4.

\section{Akty prawne}

Rozporządzenie Prezydenta Rzeczypospolitej z dnia 11 lipca 1932 r. — Kodeks karny (Dz.U. RP nr 60, poz. 571).

Ustawa z dnia 6 czerwca 1997 roku — Kodeks karny (Dz.U. z 2020 r. poz. 1444, 1517). 